\title{
PENGARUH RETURN ON EQUITY, DEBT TO EQUITY RATIO, DAN SIZE TERHADAP HARGA SAHAM PADA PERUSAHAAN MANUFAKTUR YANG TERDAFTAR DI BURSA EFEK INDONESIA
}

\author{
Marzuki', Chairil Akhyar² \\ 1,2 Fakultas Ekonomi dan Bisnis, Universitas Malikussaleh, Lhokseumawe
}

\begin{abstract}
\begin{tabular}{l|l} 
Abstrak & Tujuan penelitian ini adalah untuk menguji pengaruh Return on Equity (ROE), Debt to
\end{tabular} Equity Ratio (DER), dan ukuran perusahaan (size) terhadap harga saham pada perusahaan manufaktur yang terdaftar di Bursa Efek Indonesia (BEI). Data yang digunakan dalam penelitian ini adalah data panel yang merupakan gabungan antara cross section data dan time series data. Penelitian ini menggunakan metode purposive sampling dengan sampel penelitian terdiri dari 86 perusahaan manufaktur yang terdaftar di BEI periode tahun 2017. Metode analisis yang digunakan adalah regresi linear berganda. Hasil penelitian menunjukkan bahwa ROE dan size berpengaruh positif dan signifikan pada harga saham, sedangkan DER tidak berpengaruh signifikan pada harga saham.
\end{abstract}

Kata Kunci : $\quad$ ROE, DER, size, harga saham

\begin{tabular}{l|l} 
Abstract & $\begin{array}{l}\text { The objective of this study is to examine the effect of ROE, DER, and firm size on stock } \\
\text { prices of the manufacturing companies listed on the Indonesia Stock Exchange (IDX). The } \\
\text { data used in this study were panel data sourced from the combination of cross section } \\
\text { data and time series data. This research used purposive sampling method with the } \\
\text { sample consisted of } 86 \text { manufacturing companies listed on IDX in 2017. Data were } \\
\text { analyzed using multiple linear regression. The results showed that ROE and firm size had } \\
\text { a positive and significant influence on stock price. However, DER did not have a } \\
\text { significant influence on stock price. }\end{array}$
\end{tabular}

Keywords : ROE, DER, company size, stock price 


\section{Pendahuluan}

Pasar modal merupakan suatu tempat yang mempertemukan investor (pemodal) dengan emiten. Pemodal adalah perorangan atau lembaga yang menanamkan dananya dalam bentuk efek, sedangkan emiten adalah perusahaan yang menjual efek untuk ditawarkan kepada masyarakat. Jadi pemodal menginvestasikan modalnya kepada perusahaan yang telah menjual efeknya kepada masyarakat umum. Perkembangan pasar modal sangat dipengaruhi oleh partisipasi yang aktif baik dari perusahaan yang menjual sahamnya maupun investor serta pihak-pihak yang terlibat dalam kegiatan pasar modal (Sari dan Sapari, 2017; Suffah dan Riduwan, 2016). Ini menunjukkan bahwa tanpa adanya partisipasi yang aktif dari perusahaan-perusahaan yang potensial untuk go public, tidak adanya investor yang bergairah menanamkan dananya dalam surat berharga dan kurang aktifnya lembagalembaga penunjang pasar modal, maka suatu pasar modal tidak akan berkembang dengan baik (BEI, 2017).

Return on Equity perusahaan manufaktur di Indonesia tebilang cukup baik. Hal ini dapat dilihat dari total aset perusahaan manufaktur yang tumbuh sebesar 25,6\%. Kenaikan tersebut patut diperhitungkan karena berhasil naik dari tahun 2015 yang hanya sebesar 20,3\%. Inilah yang menyebabkan manufaktur naik daun di tahun 2017. Hal ini menjadi salah satu sektor yang memiliki total aset terbaik di tahun 2017. (BEI, 2017). Hal ini menunjukkan bahwa perusahaan manufaktur merupaka perusahaan yang diminati oleh para investor sampai di tahun 2017. Maka dari itu, perlu diketahui faktor-faktor apa saja yang mempengaruhi harga saham perusahaan manufaktur di BEI. Investor selalu melihat bagaimana kondisi harga saham sebelum melakukan keputusan untuk berinvestasti. Menurut Jogiyanto (2008) harga saham adalah harga yang terjadi di pasar bursa pada saat permintaan dan penawaran saham yang bersangkutan. Harga saham harus tetap terjaga kestabilannya. Hal ini perlu dilakukan untuk menarik perhatian investor karena investor selalu mempertimbangkan hal tersebut. Maka dari itu perusahaan harus mengetahui faktor-faktor yang dapat memengaruhi pergerakan harga saham (Hudan et al, 2016).
Profitabilitas juga dikatakan DER menjadi salah satu faktor yang dapat mempengaruhi pergerakan harga saham. Kasmir (2014) mengatakan bahwa profitabilitas merupakan kemampuan perusahaan dalam menghasilkan laba. Semakin tinggi profitabilitas perusahaan maka semakin besar peluang para investor untuk memperoleh laba bersih dari setiap modal yang diinvestasikan sehingga akan direspon positif oleh pasar (Kesuma, 2009). hal ini didukung oleh penelitian Sugeng (2015), Suyatna dan Nazar (2015), Anjarwati dan Budiyanto (2015), Shafira dan Retnani (2017), Riawan (2017) yang menemukan bahwa profitabilitas berpengaruh positif dan signifikan terhadap harga saham. Tetapi temuan berbeda diungkapkan oleh Wilianto (2012), Novitasari dan Widyawati (2015) serta Siahaan (2017) yang mengatakan bahwa profitabilitas memiliki pengaruh negatif tetapi tidak signifikan terhadap harga saham. Di sisi lain, Debt to Equity Ratio (DER) juga menjadi salah satu faktor yang dapat memengaruhi harga saham. Anjarwati dan Budianto (2015) mengatakan bahwa $D E R$ adalah rasio yang menunjukkan sejauh mana perusahaan dibiayai oleh pihak luar Semakin tinggi $D E R$ maka beban perusahaan juga akan semakin bertambah, sehingga dapat mengurangi hak pemegang saham. Hal ini mempengaruhi minat investor terhadap saham perusahaan karena investor pasti akan lebih tertarik pada saham yang tidak terlalu banyak menanggung terlalu banyak beban hutang. Hal ini sejalan dengan hasil penelitian Wilianto (2012), dan Ayu dan Suarjaya (2017) yang menemukan bahwa leverage berpengaruh negatif dan signifikan terhadap harga saham. Tetapi temuan yang berbeda diungkapkan oleh Andriky (2015), Anjarwati dan Budiyanto (2015) yang mengatakan bahwa leverage berpengaruh positif tetapi tidak signifikan terhadap harga saham.

Ukuran perusahaan (size) juga menjadi salah satu faktor yang dapat mempengaruhi harga saham suatu perusahaan. Hal ini didukung dengan hasil penelitian Pratama dan Purwanto (2014), Sugeng (2015), Shafira dan Retnani (2017) dan Riawan (2017) yang menemukan bahwa firm size berpengaruh positif dan signifikan terhadap harga saham. Tetapi temuan yang berbeda diungkapkan oleh Pratama dan Purwanto (2014) dan Hantono (2016) yang 
mengatakan bahwa ukuran perusahaan (firm size) tidak memiliki pengaruh yang signifikan terhadap harga saham. Berdasarkan fenomenafenomena yang telah diuraikan di atas, maka peneliti tertarik melakukan penelitian yang berjudul "Pengaruh ROE, DER dan size terhadap Harga Saham Pada Perusahaan Manufaktur yang Terdaftar di Bursa Efek Indonesia (BEI)".

Berdasarkan fenomena di atas, maka rumusan masalah dalam penelitian ini adalah Apakah Return on Equity, Debt to Equity Ratiodan Size berpengaruh signifikan baik secara parsiat maupun semultan terhadap harga saham pada perusahaan manufaktur yang terdaftar di BEI

Tujuan penelitian ini adalah menguji pengaruh Return on Equity, Debt to Equity Ratio dan Size terhadap harga saham pada Perusahaan Manufaktur di BEI

\section{Metodologi}

Objek dalam penelitian ini adalah, profitabilitas, leverage dan size terhadap harga saham. Adapun penelitian ini dilakukan oleh peneliti di Bursa Efek Indonesia (BEI). Untuk memperoleh informasi yang diperlukan pada penelitian ini, maka peneliti mengambil data laporan keuangan secara tahunan pada perusahaan manufaktur yang terdaftar di BEI pada tahun 2017

\section{Populasi dan Sampel}

Menurut Sugiyono (2016) populasi adalah wilayah generalisasi yang terdiri atas objek atau subjek yang mempuayai kualitas dan penelitian karakteristik tertentu yang diterapkan oleh peneliti untuk dipelajari kemudian ditarik kesimpulannya. Populasi yang digunakan dalam penelitian ini adalah perusahaan-perusahaan manufaktur yang terdaftar di BEI. Jumlah perusahaan manufaktur yang terdaftar di BEI sebanyak 128 perusahaan di tahun 2017. Menurut. Sugiyono (2016) sampel adalah bagian dari jumlah dan karakteristik yang dimiliki oleh populasi tersebut dan peneliti tidak mungkin mempelajari semua yang ada pada populasi. Misalnya karena keterbatasan dan tenaga, dan waktu, maka penulis dapat menggunakan sampel yang diambil dari populasi itu apa yang dipelajari dari sampel itu kesimpulannya akan dapat diberlakukan untuk populasi. Untuk itu sampel yang diambil dari populasi harus betul-betul representatif (mewakili). Adapun metode pengambilan sampel dalam penelitian ini adalah metode purposive sampling. Menurut Sugiyono (2016) purposive sampling adalah teknik pengambilan sampel yang didasarkan pada tujuan penelitian. Dalam teknik ini, sampel harus memenuhi kriteria sebagai berikut :

1. Perusahaan manufaktur yang terdaftar di Bursa Efek Indonesia dan mempublikasikan laporan keuangan pada tahun 2017.

2. Perusahaan tersebut menerbitkan laporan tahunan dan catatan atas laporan keuangan pada tahun 2017.

3. Perusahaan tidak mengalami delisting dari Bursa Efek Indonesia.

4. Mempunyai data yang dibutuhkan dalam penelitian.

Berdasarkan kriteria tersebut, maka yang menjadi sampel dalam penelitian ini sebanyak 86 perusahaan perusahaan manufaktur yang terdaftar di Bursa Efek Indonesia. Jenis data yang digunakan dalam penelitian ini adalah data panel yang merupakan gabungan antara cross section data dan time series data. Data panel tersebut merupakan data sekunder yang bersumber dari laporan keuangan perusahaan manufaktur yang terdaftar di Bursa Efek Indonesia (BEI) yang diunduh melalui situs resmi BEI yaitu www.idx.co.id.

\section{Definisi Operasional Variabel}

Dalam penelitian ini menggunakan variabel dependen dan variabel independen. Sugiyono (2016) menyatakan variabel independen adalah sejumlah gejala dengan berbagai unsur atau faktor yang didalamnya menentukan atau mempengaruhi adanya variabel-variabel yang lain. Sedangkan variabel dependen adalah sejumlah gejala dengan berbagai unsur atau faktor di dalamnya yang ada ditentukan atau dipengaruhi oleh adanya variabel lain. Variabel dependen (variabel terikat) merupakan tipe variabel yang dipengaruhi oleh variabel lain. Variabel dependen ( $\mathrm{Y}$ ) dalam penelitian ini adalah harga saham. Harga saham adalah sebesar nilai sekarang atau present value dari aliran kas yang diharapkan. Harga saham yang diambil pada penelitian ini adalah harga saham tahunan perusahaan manufaktur yang terdaftar 
di BEI yang ditutup (closed) setiap akhir tahun (31 Desember).

Variabel independen (variabel bebas) merupa kan tipe variabel yang dapat mempengaruhi variabel lain. Variabel independen dalam penelitian ini adalah Profitabilitas atau ROE, leverage atau DER dan Size.

Profitabilitas atau ROE (X $\left.\mathrm{X}_{1}\right)$ merupakan kemampuan perusahaan dalam memperoleh laba. Dalam penelitian ini, profitabilitas diproksikan dengan rasio Return on Equity (ROE). ROE adalah rasio profitabilitas yang mengukur kemampuan perusahaan memperoleh laba yang didasarkan atas ekuitas perusahaan. Leverage atau DER $\left(\mathrm{X}_{2}\right)$ adalah rasio yang mengukur perbandingan hutang terhadap ekuitas perusahaan. Dalam penelitian ini, rasio yang digunakan untuk memproksikan leverage adalah Debt to Equity Ratio (DER). Size $\left(\mathrm{X}_{3}\right)$ adalah ukuran yang dimiliki oleh perusahaan yang dapat dilihat berdasarkan aktivanya.

\section{Metode Analisis Data}

Metode yang digunakan untuk mendukung penelitian ini adalah metode kuantitatif dan dalam penelitian ini menggunakan model regresi linear berganda. Model regresi linear berganda adalah model pengujian statistik yang bertujuan untuk menganalisis pengaruh variabel dependen (bebas) terhadap variabel dependen (terikat). Adapun persamaan regresi dapat diformulasikan sebagai berikut :

$$
\mathrm{Y}=\alpha+\beta 1 R O E+\beta_{2} D E R+\beta_{3} \text { Size }+\mathrm{e}
$$

\section{Keterangan:}

\begin{tabular}{|c|c|c|}
\hline Y & $=$ & Harga Saham \\
\hline$\alpha$ & $=$ & Konstanta \\
\hline$\beta_{1}, \beta_{2}$, dan $\beta_{3}$ & $=$ & Koefisien regresi \\
\hline ROE & $=$ & Return on Equity \\
\hline DER & $=$ & Debt to Equity Ratio \\
\hline Size & $=$ & Ukuran Perusahaan \\
\hline & $=$ & Error term \\
\hline
\end{tabular}

\section{Hasil dan Pembahasan}

Penelitian ini memliki populasi seluruh perusahaan manufaktur yang tercatat di Bursa Efek Indonesia hingga penelitian ini dilaksanakan, yaitu per 31 Desember 2017. Menurut BEI, sektor-sektor yang tergolong sebagai perusahaan manufaktur adalah perusahaan yang bergerak di bidang industri dasar dan kimia, aneka industri dan industri barang konsumsi Adapun 86 dari 141 emiten sektor manufaktur menjadi sampel karena memenuhi seluruh kriteria sampel berdasarkan teknik purposive sampling.

\section{Analisis Deskriptif Statistik}

Analisis desktiptif dilakukan untuk mengetahui tentang desktipsi data yang digunakan dalam penelitian. Pada analisis deskriptif, akan terlihat bagaimana rata-rata, nilai maksimum, minimum, standar deviasi dan jumlah observasi pada data yang digunakan dalam penelitian ini. Adapun hasil analisis deskriptif dalam penelitian ini adalah sebagai berikut:

\section{Tabel 1. Analisis Deskriptif Statistik}

\begin{tabular}{lcrrrr}
\hline Variable & N & Min & Max & Mean & $\begin{array}{c}\text { Std.Devi } \\
\text { ation }\end{array}$ \\
\hline Harga Sa & & 1.76 & 63900 & 2794.33 & 8200.83 \\
ham (Rp) & 86 & 1.76 & & & \\
ROE (\%) & 86 & -99.05 & 143.96 & 9.55 & 30.58 \\
DER (\%) & 86 & -5.09 & 5.95 & 1.13 & 1.45 \\
SIZE (Ln) & 86 & 8.95 & 19.75 & 14.73 & 1.93 \\
\hline
\end{tabular}

Sumber: Hasil Olah Data

Berdasarkan Tabel 1 di atas, terlihat bahwa banyaknya observasi yang dilakukan untuk harga saham di dalam penelitian ini adalah 86 observasi. Nilai terendah harga saham dalam penelitian ini adalah sebesar Rp 1,76 dan nilai tertingginya adalah sebesar Rp 63.900. Adapun nilai rata-rata harga saham adalah sebesar $\mathrm{Rp}$ 2.794,33 dengan nilai standar deviasi sebesar $8.200,83$. Nilai rata-rata lebih kecil dari pada nilai standar deviasi yang artinya fluktuasi variabel harga saham di dalam penelitian ini adalah fluktuasi yang besar. Observasi yang dilakukan untuk ROE di dalam penelitian ini adalah sebanyak 86 observasi dengan nilai terendah sebesar $-99,05 \%$ dan nilai tertinggi adalah $143,96 \%$. Nilai rata-rata ROE di dalam penelitian ini adalah sebesar 9,55\% dengan nilai standar deviasi sebesar $30,58 \%$. Nilai ratarata berada di bawah nilai standar deviasi yang menunjukkan bahwa fluktuasi ROE di dalam penelitian ini merupakan fluktuasi yang besar. 
Adapun observasi yang dilakukan untuk DER di dalam penelitian ini adalah sebanyak 86 observasi dengan nilai terendah sebesar $-5,09 \%$ dan nilai tertinggi adalah $5,96 \%$. Nilai rata-rata DER di dalam penelitian ini adalah sebesar $1,13 \%$ dengan nilai standar deviasi sebesar $1,45 \%$. Nilai rata-rata berada di bawah nilai standar deviasi yang menunjukkan bahwa fluktuasi DER di dalam penelitian ini merupakan fluktuasi yang besar. Sedangkan observasi yang dilakukan untuk Size di dalam penelitian ini adalah sebanyak 86 observasi dengan nilai terendah sebesar 8,95 dan nilai tertinggi adalah 19,75. Nilai rata-rata Size di dalam penelitian ini adalah sebesar 14,73 dengan nilai standar deviasi sebesar 1,93. Nilai rata-rata berada di atas nilai standar deviasi yang menunjukkan bahwa fluktuasi Size di dalam penelitian ini merupakan fluktuasi yang kecil.

\section{Uji Asumsi Klasik}

Salah satu pengujian yang harus dilewati dalam analisis regresi linear berganda adaah uji asumsi klasik. Ghozali (2011) mengatakan bahwa uji asumsi klasik dilakukan agar model regresi linier berganda memenuhi kriteria BLUE (Based Linear Unbiased Estimator). Adapun tahapan-tahapan pengujian dalam uji asumsi klasik adalah sebagai berikut:

\section{$\underline{\text { Uji Normalitas }}$}

Uji normalitas adalah uji untuk melihat apakah data terdistribusi normal atau tidak. Ghozali (2011) mengatakan bahwa data yang baik di dalam suatu penelitian adalah data yang terdistribusi secara normal. Pengujian normalitas dapat dilakukan dalam dua cara, yaitu secara analisis grafik dan analisis statistik.

\section{$\underline{\text { Analisis Grafik }}$}

Untuk melihat data terdistribusi normal atau tidak, maka dapat dilihat pada grafik pp-plot. Dasar pengambilan keputusan di dalam $p p$ plot yaitu dengan melihat titik-titik yang ada di dalamnya. Apabila titik-titik tersebut berada di sekitar garis diagonal dan bergerak mengikutinya maka dapat disimpukan data di dalam penelitian ini terdistribusi secara normal. Adapun hasil pengujian normalitas berdasarkan analisis grafik adalah sebagai berikut:

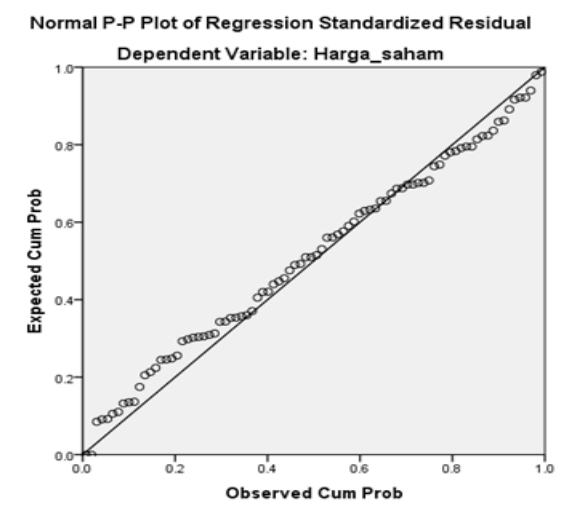

\section{Gambar 1. Uji Normalitas dengan PP-Plot Sumber: Hasil Olah Data}

Berdasarkan Gambar 2 di atas, titik-titik bergerak mendekat dan sejajar serta mengikuti garis diagonal pada grafik tersebut. Oleh karena itu, dapat disimpulkan bahwa berdasarkan PPPlot data di dalam penelitian ini terdistribusi secara normal.

\section{$\underline{\text { Analisis Statistik }}$}

Untuk mengetahui kenormalan data secara analisis statistik maka dilakukan uji non parametrik Kormoglorov Smirnov Test atau Uji KS. Dasar pengambilan keputusan pada Uji KS adalah dengan melihat nilai signifikansinya. Jika signifikansi Uji KS berada di atas nilai kesalahan yaitu 0,05 maka dapat disimpulkan bahwa data terdistribusi normal. Adapun hasil Uji KS pada penelitian ini terlihat pada tabel di bawah ini:

Tabel 2. Uji Normalitas dengan KS Test

\begin{tabular}{llr}
\hline & & $\begin{array}{r}\text { Unstandardize } \\
\text { d Residual }\end{array}$ \\
\hline $\mathrm{N}$ & Mean & 86 \\
NormalParameters & abb & .0000000 \\
& Std. & 1.51043071 \\
& Deviation & .079 \\
Most Extreme & Absolute & .055 \\
Differences & Positive & -.079 \\
& Negative & .079 \\
\hline Test Statistic & & $.200^{\mathrm{c}, \mathrm{d}}$ \\
Asymp. Sig. (2-tailed) & &
\end{tabular}

Sumber: Hasil Olah Data

Berdasarkan Tabel 2 di atas, nilai Asymp Sig (2 tailed) pada Uji KS di dalam penelitian ini adalah sebesar 0,200. Nilai tersebut berada di atas nilai kesalahan di dalam penelitian ini yaitu 0,05. Maka dari itu, dapat disimpukan bahwa 
berdasarkan Uji KS data di dalam penelitian ini sudah terdistribusi normal.

\section{Uji Heteroskedastisitas}

Uji Heteroskedastisitas bertujuan untuk menguji apakah dalam model regresi terjadi ketidaksamaan variance dari residual satu pengamatan ke pengamatan yang lain. Ghozali (2011) mengatakan bahwa model regresi yang baik adalah yang tidak terjadi heteroskedasitas. Cara yang paling umum yang digunakan untuk mendeteksi ada atau tidaknya heteroskedastisitas adalah dengan melihat scatterplot antara nilai prediksi variabel terikat (dependen) yaitu ZPRED dengan residualnya SRESID. Adapun hasil uji heteroskedastisitas dalam penelitian ini adalah sebagai berikut:

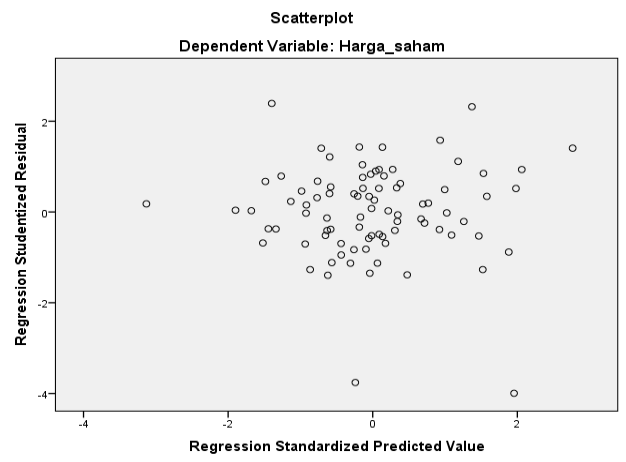

\section{Gambar 2. Uji Heteroskedastisitas (Scatterplot)}

Sumber: Hasil Olah Data

Berdasarkan Gambar 3 di atas terlihat bahwa titik-titik berada di atas dan di bawah garis nol pada sumbu Y. Sementara itu, terlihat juga bahwa titik-titik menyebar secara merata dan tidak membentuk suatu pola apapun. Maka dari itu, dapat disimpulkan bahwa penelitian ini bebas dari gejala heteroskedastisitas. Akan tetapi, terdapat banyak perbedaan pendapat dan pandangan dalam pengambilan keputusan jika hanya melihat hasil uji heteroskedastisitas secara grafik. Maka dari itu, dapat dilakukan uji statistik non parametrik untuk melihat apakah dalam model terdapat gejala heteroskedastisitas ataupun tidak. Uji non parametrik tersebut adalah Uji Park (Park Test). Dasar pengambilan keputusan pada Uji Park yaitu dengan melihat nilai signifikansinya. Jika nilai signfikansi berada di atas 0,05 maka dapat disimpulkan bahwa tidak terjadi gejala heteroskedastisitas. Adapun hasil Uji Park dalam penelitian ini adalah sebagai berikut:
Tabel 3. Uji Park

\begin{tabular}{lrr}
\hline \multicolumn{1}{c}{ Model } & \multicolumn{1}{c}{$\mathrm{t}$} & \multicolumn{1}{c}{ Sig. } \\
\hline (Constant) & -1.990 & .050 \\
ROE & .477 & .634 \\
DER & 1.572 & .120 \\
SIZE & 1.605 & .112 \\
\hline
\end{tabular}

Sumber: Hasil Olah Data

Berdasarkan Tabel 3 di atas, terlihat bahwa seluruh nilai signifikansi Uji Park variabel bebas yang terdiri dari ROE, DER dan Size memiliki nilai signifikansi di atas 0,05. Oleh karena itu, dapat disimpulkan bahwa penelitian ini bebas dari gejala heteroskedastisitas.

\section{$\underline{\text { Uji Multikolinearitas }}$}

Uji multikolinearitas adalah salah satu pengujian di dalam asumsi klasik yang berguna untuk melihat apakah variabel-variabel independen di dalam penelitian memiliki hubungan atau tidak. Ghozali (2011) mengatakan bahwa model regresi linear berganda yang baik tidak memiliki hubungan di antara variabel-variabel bebasnya. Adanya Multikolinearitas dapat dilihat dari tolerance value atau nilai varience inflation factor (VIF). Batas dari tolerance value di atas 0,10 atau nilai VIF di bawah 10. Adapun hasil uji multikolinearitas dalam penelitian ini adalah sebagai berikut:

Tabel 4. Uji Multikolinearitas

\begin{tabular}{lcc}
\hline \multicolumn{1}{c}{ Model } & Tolerance & VIF \\
\hline (Constant) & & \\
ROE & .912 & 1.097 \\
DER & .960 & 1.041 \\
SIZE & .937 & 1.067 \\
\hline
\end{tabular}

Sumber: Hasil Olah Data

Berdasarkan Tabel 4 di atas, terlihat bahwa seluruh nilai tolerance berada di atas 0,1 dan seluruh nilai VIF berada di bawah 10. Maka dapat disimpulkan bahwa tidak terjadi gejala multikolinearitas di dalam penelitian ini. Artinya variabel bebas dalam penelitian ini yang terdiri dari ROE, DER dan Size tidak memiliki hubungan korelasi yang tinggi.

\section{$\underline{\text { Uji Autokorelasi }}$}

Uji autokorelasi adalah suatu uji yang bertujuan untuk mengetahui apakah dalam suatu model 
linear ada korelasi antara kesalahan penganggu pada periode $t$ dengan kesalahan pada periode t-1. Ghozali (2011) mengatakan bahwa model regresi linear berganda yang baik tidak boleh terdapat autokorelasi. Uji autokorelasi dapat dilihat dari nilai Durbin Watson. Nilai Durbin Watson yang menunjukkan bahwa tidak terjadi autokorelasi di dalam suatu penelitian adalah berada di rentang bilangan -2 sampai 2. Nilai Durbin Watson di dalam penelitian ini adalah sebesar 1,762. Nilai tersebut berada di rentang bilangan -2 dan 2. Oleh karena itu, dapat disimpulkan bahwa penelitian ini terbebas dari gejala autokorelasi.

Variabel bebas di dalam penelitian ini terdiri dari ROE, DER dan Size dan variabel terikat yaitu harga saham. Hasil regresi linear berganda di dalam penelitian ini adalah sebagai berikut:

\section{Tabel 5. Estimasi Regresi Linear Berganda}

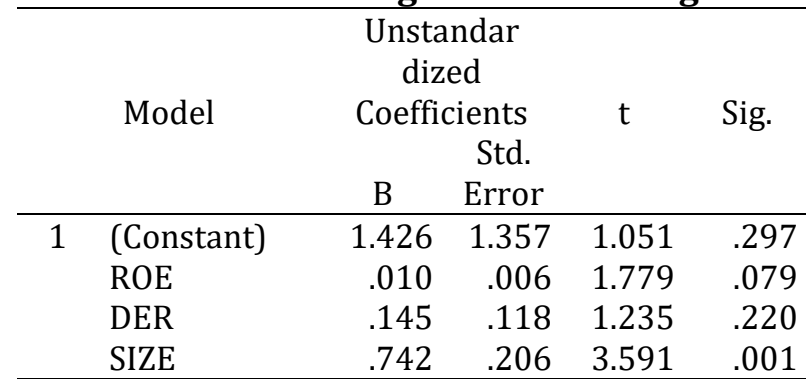

Sumber : Hasil Olah Data

Berdasarkan Tabel 5 di atas, maka persamaan regresi berganda yang dapat disusun di dalam penelitian ini adalah sebagai berikut:

$$
Y=1,426+0,010 \mathrm{ROE}+0,145 \mathrm{DER}+0,742 \text { Size }
$$

Terlihat pada persamaan di atas, maka penjelasan hubungan seluruh variabel bebas yaitu ROE, DER, dan Size terhadap harga saham adalah sebagai berikut:

1. Konstanta sebesar 1,426 yang menunjukkan bahwa jika ROE, DER, dan Size bernilai 0 maka harga saham akan tetap konstan dengan nilai 1,426.

2. ROE memiliki hubungan positif terhadap harga saham dengan koefisien regresi sebesar 0,010. Hal ini menunjukkan bahwa jika ROE ditambah sebesar 1\% maka harga saham akan naik sebesar $0,010 \%$.

3. DER memiliki hubungan positif terhadap harga saham dengan koefisien regresi sebesar 0,145. Hal ini menunjukkan bahwa jika DER ditambah sebesar 1\% maka harga saham akan naik sebesar 0,145\%.

4. Size memiliki hubungan positif terhadap harga saham dengan koefisien regresi sebesar 0,742. Hal ini menunjukkan bahwa jika Size ditambah sebesar 1\% maka harga saham akan naik sebesar $0,742 \%$.

Untuk melihat pengaruh seluruh variabel independen yang terdiri dari profitabilitas, leverage dan size terhadap variabel dependen yaitu harga saham secara parsial maka dapat dilihat dengan melakukan uji t. Dasar pengambilan keputusan pada Uji t yaitu dengan membandingkan nilai $t_{\text {hitung }}$ dengan $t_{\text {tabel }}$ dan melihat nilai signifikansinya. Adapun level kesalahan yang digunakan untuk pengujian hipotesis di dalam penelitian ini adalah 0,1.

Tabel 6. Hasil Pengujian Hipotesis

\begin{tabular}{cccccl}
\hline $\begin{array}{c}\text { Hipote } \\
\text { sis }\end{array}$ & Var & $t_{\text {hitung }}$ & \multicolumn{1}{c}{ ttabel } & Sig & \multicolumn{1}{c}{ Ket } \\
\hline $\mathrm{H}_{1}$ & ROE & 1.779 & 1.6638 & 0.079 & Diterima \\
$\mathrm{H}_{2}$ & DER & 1.235 & 1.6638 & 0.220 & Ditolak \\
$\mathrm{H}_{3}$ & Size & 3,591 & 1.6638 & 0.001 & Diterima \\
\hline
\end{tabular}

Sumber : Hasil Olah Data

Berdasarkan Tabel 6, terlihat bahwa nilai $t_{\text {hitung }}$ ROE sebesar 1,779 dengan nilai signifikansi sebesar 0,079. Adapun nilat $t_{\text {tabel }}$ dihitung dengan $\mathrm{df}=86-5$ pada level signifikansi $10 \%$ menghasilkan angka 1,6638. Oleh karena itu, $t_{\text {hitung }}(1,779)>t_{\text {tabel }}(1,6638)$ dan nilai signifikansi $(0,079)<0,1$ maka $\mathrm{H}_{2}$ diterima yang artinya profitabilitas berpengaruh positif dan signifikan terhadap harga saham perusahaan manufaktur di BEI.

Hasil penelitian ini sejalan dengan temuan Sugeng (2015), Suyatna dan Nazar (2015), Anjarwati dan Budiyanto (2015), Shafira dan Retnani (2017), Riawan (2017) yang menemukan bahwa profitabilitas berpengaruh positif dan signifikan terhadap harga saham. Tetapi hasil penelitian ini bertentangan dengan temuan Wilianto (2012), Novitasari dan Widyawati (2015) serta Siahaan (2017) yang mengatakan bahwa profitabilitas memiliki pengaruh negatif tetapi tidak signifikan terhadap harga saham. Temuan ini mengindikasikan bahwa kinerja keuangan perusahaan merupakan faktor yang mampu mempengaruhi harga saham perusahaan. Tingginya profitabilitas perusahaan menunjukkan bahwa perusahaan tersebut 
merupakan perusahaan dengan laba tinggi. Hal ini tentunya membuat perusahaan tersebut memiliki prospek yang cerah di masa depan yang menyebabkan harga saham perusahaan tersebut naik di pasar modal.

Berdasarkan Tabel 6, terlihat bahwa nilai $t_{\text {hitung }}$ DER sebesar 1,235 dengan nilai signifikansi sebesar 0,220. Adapun nilat $t_{\text {tabel }}$ dihitung dengan $\mathrm{df}=86-5$ pada level signifikansi $10 \%$ menghasilkan angka 1,6638. Oleh karena itu, $t_{\text {hitung }}(1,235)<t_{\text {tabel }}(1,6638)$ dan nilai signifikansi $(0,220)>0,1$ maka $\mathrm{H}_{3}$ ditolak yang artinya leverage tidak berpengaruh signifikan terhadap harga saham perusahaan manufaktur di BEI. Hasil penelitian ini sejalan dengan temuan Andriky (2015), Anjarwati dan Budiyanto (2015) yang mengatakan bahwa leverage tidak berpengaruh signifikan terhadap harga saham. Sementara itu, hasil penelitian ini bertolak belakang dengan temuan Wilianto (2012) dan Ayu dan Suarjaya (2017) yang menemukan bahwa leverage berpengaruh negatif dan signifikan terhadap harga saham.

Temuan ini mengindikasikan bahwa kebijakan hutang perusahaan tidak berpengaruh terhadap harga saham perusahaan di pasar modal. Hal ini menunjukkan bahwa pada Perusahaan Manufaktur banyak investor yang bertipe berani mengambil risiko. Investor beranggapan bahwa risiko yang tinggi akan menghasilkan pengembalian yang tinggu juga. Selain itu, investor beranggapan bahwa tingginya kebijakan hutang bukan berarti perusahaan tersebut sedang terpuruk, tetapi perusahaan tersebut sedang ingin melakukan pengembangan usaha dengan menggunakan modal dari pihak ketiga. Maka dari itu, leverage bukanlah faktor yang mempengaruh tingginya harga saham perusahaan.

Berdasarkan Tabel 6, terlihat bahwa nilai thitung Size sebesar 3,591 dengan nilai signifikansi sebesar 0,001. Adapun nilat $t_{\text {tabel }}$ dihitung dengan $\mathrm{df}=86-5$ pada level signifikansi $10 \%$ menghasilkan angka 1,6638. Oleh karena itu, $t_{\text {hitung }}(3,591)>t_{\text {tabel }}(1,6638)$ dan nilai signifikansi $(0,001)<0,1$ maka $\mathrm{H}_{4}$ diterima yang artinya size berpengaruh positif dan signifikan terhadap harga saham perusahaan manufaktur di BEI. Hasil penelitian ini sejalan dengan temuan Pratama dan Purwanto (2014), Sugeng (2015), Shafira dan Retnani (2017) dan Riawan
(2017) yang menemukan bahwa firm size berpengaruh positif dan signifikan terhadap harga saham. Tetapi hasil penelitian ini bertentangan dengan temuan Pratama dan Purwanto (2014) dan Hantono (2016) yang mengatakab bahwa ukuran perusahaan (firm size) tidak memiliki pengaruh yang signifikan terhadap harga saham.

Temuan ini mengindikasikan bahwa ukuran perusahaan merupakan faktor yang mampu mempengaruhi kenaikan harga saham secara signifikan. Tingginya aset perusahaan mengindikasikan bahwa perusahaan tersetbu memiliki jaminan yang tinggi sehingga risiko untuk bangkrut berkurang. Hal ini membuat investor tertarik untuk membeli saham perusahaan sehingga permintaan saham meningkat dan harga saham ikut naik.

\section{Kesimpulan}

Berdasarkan hasil analisis data secara regresi linear berganda dan hasil pengujian hipotesis yang telah dilakukan dengan derajat signifikan 0,1 (10\%), maka dapat disimpulkan bahwa ROE memiliki pengaruh positif dan signifikan terhadap harga saham. Hal tesebut menunjukkan bahwa naiknya harga saham dipengaruhi oleh seberapa besar kinerja keuangan perusahaan. Di sisi lain, Size juga memiliki pengaruh yang positif dan signifikan terhadap harga saham. Hal tersebut menunjukkan bahwa naiknya harga saham disebabkan oleh tingginya aset yang perusahaan miliki. Hasil pengujian hipotesis juga menemukan bahwa DER tidak berpengaruh signifikan terhadap harga saham. Hal ini menunjukkan bahwa permintaan saham yang tinggi oleh investor tidak didasarkan pada tingginya pemberian divden persahaan Sementara itu, DER tidak berpengaruhi signifikan terhadap harga saham. Hal tersebut menunjukkan bahwa investor tidak menilai tingkat struktur modal perusahaan. Maka dapat disimpulkan bahwa investor tidak melihat penjualan dan pemberian dividen yang dilakukan perusahaan untuk bertransaksi di pasar modal.

\section{Saran}

Saran pada penelitian ini yaitu kepada para perusahaan untuk meningkatkan kinerja 
keuangan perusahaan dan juga aset perusahaan agar harga saham perusahaan dapat meningkat. Selain itu, disarankan kepada perusahaan untuk tidak takut dalam menggunakan modal eksternal dan memberikan dividen yang tinggi kepada para investor. Hal ini dikarenakan leverage tidak mempengaruhi harga saham. Disarankan kepada para investor untuk melihat tingkat aset dan profitabilitas perusahaan dalam menilai harga saham perusahaan. Sementara itu, disarankan kepada investor untuk tidak takut berinvestasi pada perusahaan yang leveraged karena hal tersebut tidak berpengaruh terhadap harga saham perusahaan

\section{Daftar Referensi}

Andriky, Vicky. 2015. Pengaruh Leverage dan Earning Per Share Terhadap Harga Saham Pada Perusahaan Automotive And Allied Products Yang Terdaftar Di Bursa Efek Indonesia. Fakultas Ekonomi dan Bisnis Universitas Negeri Lampung. Skripsi. Dipublikasikan.

Anjarwati, Dwi dan Budiyanto. 2015. Pengaruh Profitabilitas, Leverage dan Nilai Pasar Terhadap Harga Saham. Jurnal Ilmu dan Riset Manajemen. Vol 4. No 10.

Ayu, Dea Putri dan Suarjaya, A.A. Gede. 2017. Pengaruh Profitabilitas Terhadap Nilai Perusahaan dengan Corporate Social Responsibility Sebagai Variabel Mediasi Pada Perusahaan Pertambangan. E-Jurnal Manajemen Unud. Vol 6. No 2.

Bursa Efek Indonesia. www.idx.co.id. Diakses pada 16 November 2017.

Hantono. 2016. Pengaruh Ukuran Perusahaan, Total Hutang, Current Ratio, Terhadap Kinerja Keuangan dan Harga Saham Sebagai Variabel Moderating. Jurnal Wira Ekonomi Mikroskil. Vol 6. No 1.

Kasmir. 2014. Analisis Laporan Keuangan. Jakarta: Rajawali Pers,

Kesuma, Ali. 2009. Analisis Faktor yang Memperngaruhi Struktur Modal serta Pengaruhnya terhadap Harga Saham Perusahaan Real Estate yang Go-Public di BEI. Jurnal Manajemen dan Kewirausahaan. Vol 2. No 1.
Novitasari, Bunga dan Dini Widyawati. 2015. Pengaruh Profitabilitas, Pertumbuhan Penjualan dan Kebijakan Dividen Terhadap Harga Saham. Jurnal Ilmu \& Riset Akuntansi. Vol 4. No 2.

Pratama, Bhagas Adhitya Ardia dan Purwanto, Agus .2014. Pengaruh Economic Value Added (EVA), Profitabilitas, Kebijakan Dividen dan Pertumbuhan Penjualan terhadap Harga Saham. Diponegoro Journal of Accounting. Volume 3. Nomor 3.

Riawan. 2017. Pengaruh Kebijakan Dividen dalam Memediasi Return On Asset dan Firm Size Terhadap Harga Saham. Jurnal Akuntansi dan Pajak. Vol 17. No 02.

Sari, Oktavia Kartika dan Sapari. 2017. Pengaruh Pertumbuhan Penjualan, Earning Per Share, dan Kebijakan Dividen terhadap Harga Saham. Jurnal Ilmu dan Riset Akuntansi. Vol 6. No 8.

Shafira, Annisa Prily Bertha dan Retnani, Endang Dwi. 2017. Pengaruh Kinerja Keuangan, Kebijakan Dividen dan Ukuran Perusahaan Terhadap Harga Saham LQ45. Jurnal Ilmu dan Riset Akuntansi. Volume 6. Nomor 4

Siahaan, Dhani Beslyder. 2017. Pengaruh PBV, DER dan ROE terhadap Harga Saham Perusahaan Manufaktur yang Terdaftar di Bursa Efek Indonesia. eJournal Administrasi Bisnis. Vol 5. No 3.

Suffah, Roviqotus dan Riduwan, Akhmad. 2016. Pengaruh Profitabilitas, Leverage, Ukuran Perusahaan dan Kebijakan Dividen Pada Nilai Perusahaan. Jurnal Ilmu dan Riset Akuntansi. Volume 5. Nomor 2.

Sugeng. 2015. Pengaruh Profitabilitas, Solvabilitas, Ukuran Perusahaan Terhadap Harga Saham yang Dimoderasi Perataan Laba Pada Perusahaan Manufaktur yang Terdaftar di Bursa Efek Indonesia. Cendikia Akuntansi. Vol 3. No 3.

Sugiyono. 2016. Metode Penelitian Kuantitatif, Kualitatif dan R\&B., Bandung:Alfabeta

Suyatna, Oggi Bagus dan Nazar, Mohamad Rafky. 2015. Pengaruh Return On Equity, Pertumbuhan Penjualan, Dividen, dan Inflasi terhadap Harga Saham Pada Perusahaan Food and Beverage. E-Proceeding of Management. Vol 2. No 2. 
Wilianto, Arief. 2012. Pengaruh Kebijakan Dividen, Leverage Keuangan dan Profitabilitas Terhadap Harga Saham Perusahaan Manufaktur di BEI. Jurnal Ilmiah Mahasiswa Akuntansi. Vol 1. No 2. 